\title{
PEMBELAJARAN KOOPERATIF TIPE TGT (TEAMS GAMES TOURNAMENT) UNTUK MENINGKATKAN HASIL BELAJAR MATEMATIKA
}

\author{
Septia Eka Cahya Arum Lestari ${ }^{1}$, Sri Hariyani ${ }^{2}$, Nyamik Rahayu ${ }^{3}$ \\ ${ }^{1,2,3}$ Program Studi Pendidikan Matematika, Universitas Kanjuruhan Malang \\ septiaekacarumles@gmail.com \\ srihariyani@unikama.ac.id \\ nyamik@unikama.ac.id
}

\begin{abstract}
Abstrak: Pembelajaran yang kurang bervariasi pada siswa kelas VII-B SMP PGRI 6 Malang menyebabkan siswa bosan dalam pembelajaran, sehingga siswa cenderung menjadi pendengar saja. Hal ini mengakibatkan hasil belajar siswa tidak sesuai dengan KKM yang telah ditetapkan. Oleh karena itu, perlu digunakan metode pembelajaran menarik yang dapat meningkatkan hasil belajar siswa.Penelitian ini bertujuan untuk mendiskripsikan penerapan pembelajaran kooperatif tipe $T G T$ yang dapat meningkatkan hasil belajar matematikapada siswa kelas VII-B SMP PGRI 6 Malang. Penelitian ini merupakan penelitian kualitatif dengan jenis penelitian tindakan kelas (PTK). Sumber data dalam penelitian ini adalah siswa kelas VIIB SMP PGRI 6 Malang dan peneliti yang bertindak sebagai guru. Prosedur pengumpulan data yang digunakan meliputi tes tulis, observasi, dan wawancara. Teknik analisis data yang digunakan meliputi mereduksi data, menyajikan data dan menarik kesimpulan. Hasil penelitian menunjukkan bahwa presentase ketuntasanhasil belajar matematika meningkat dari 63,6\% siswa yang tuntas pada siklus I menjadi $83,3 \%$ siswa yang tuntas pada siklus II.Dengan demikian, peningkatan hasil belajar siswa sebesar 19,7\%,Sehingga terbukti bahwa model pembelajaran Teams Games Tournament mampu meningkatkan hasil belajar matematika siswa.
\end{abstract}

Kata Kunci: Teams Games Tournament; Hasil Belajar.

\section{Pendahuluan}

Matematika merupakan ilmu universal yang mendasari perkembangan tekonologi modern dalam bidang informasi dan komunikasi. Dalam perkembangan peradaban modern, matematika memegang peranan penting karena semua ilmu pengetahuan lainnya membutuhkan ilmu matematika. Begitupun dalam kehidupan sehari-hari, matematika dapat digunakan untuk berdagang, berbelanja, berkomunikasi dan lain sebagainya. Oleh karenanya matematika diberikan kepada semua peserta didik mulai dari sekolah dasar sampai perguruan tinggi.

Fungsi dan peran matematika tersebut tidak sejalan dengan proses pembelajaran di sekolah. Matematika dianggap sebagai mata pelajaran yang sulit bagi kebanyakan siswa. Mereka memandang bahwa matematika adalah pelajaran yang kurang menarik, sulit dipelajari, membingungkan, membosankan dan tidak mempunyai nilai guna yang langsung berhubungan dengan kehidupan sehari-hari.Siswa memaknai matematika hanya sebagai aturan prosedural yang harus dihapal (Hariyani, 2018).

Kesulitan belajar siswa tidak hanya berasal dari siswa sendiri, tetapi guru juga ikut andil terjadinya kesulitan tersebut, seperti proses pembelajaran dilakukan dengan menggunakan model pembelajaran yang kurang bervariasi, sehingga siswa bosan dan tidak konsentrasi dalam mengikuti proses belajar. Begitupun ketika diskusi, biasanya guru mengelompokkan siswa 
dengan teman sebangkunya. Cara pengelompokan seperti ini menimbulkan kesenjangankarena komposisi kelompok yang tidak berimbang, ada kelompok yang anggotanya memiliki kemampuan tinggi, ada pula kelompok yang memiliki kemampuan rendah. Dengan demikian, tidak akan terjadi interaksi antarsiswa. Siswa yang pandai tidak dapat menularkan pengetahuan kepada siswa yang kurang pandai.Selama ini media yang digunakan guru hanya modul atau buku paket. Setelah berceramah atau menjelaskan materi, biasanya guru menugaskan siswa untuk mengerjakan soal-soal dalam buku. Situasi ini berlangsung seterusnya sehingga siswa merasa jenuh dalam pembelajaran.

Permasalahan pembelajaran matematika di atas juga terjadi pada siswa kelas VII-B SMP PGRI 6 Malang. Berdasarkan observasi yang dilakukan, data nilai ulangan dari guru mata pelajaran matematika menunjukkan ratarata nilai siswa adalah 63,6dengan kriteria ketuntasan minimal 71.Terdapat $32,1 \%$ siswa yang tuntas belajar, sedangkan $67,9 \%$ siswa tidak tuntas belajar.

$$
\text { Peneliti juga melakukan }
$$
wawancara kepada siswa kelas VII-B SMP PGRI 6 Malang yang bertujuan untuk mengetahui kondisi siswa sebenarnya. Melalui wawancara tersebut peneliti dapat menyimpulkan pelajaran matematika adalah mata pelajaran yang kurang diminati bagi sebagian besar siswa karena dianggap sulit dan membosankan. Selain itu, peneliti juga melakukan wawancara dengan guru matematika. Hasil wawancara menunjukkan bahwa kelas VII-B merupakankelompok siswa dengan hasil seleksi nilai per semester termasuk kategori kemampuan rata-rata menengah kebawah. Oleh karenanya guru menjadikannyasebagai alasan bahwa kelas ini hanya dilakukan pembelajaran
monoton.Input siswa yang rata-rata memiliki kemampuan menengah kebawah dianggap tidak mampu untuk menjalankan pembelajaran yang bervariasi.

Berdasarkan permasalahan yang dikemukakan diatas, perlu diadakan upaya perbaikan praktek belajar untuk mengubah pandangan negatif siswa terhadap matematika.Peneliti menetapkan alternatifdengan menerapkan model pembelajaran menyenangkan dan berpusat pada siswa. Model pembelajaran yang diterapkan yaitu pembelajaran kooperatif tipe TGT (Teams Games Tournament).

Pembelajaran kooperatif membuat siswa dapat terlibat aktif pada proses pembelajaran,hal ini memberikan dampak positif terhadap kualitas interaksi dan komunikasi yang dapat memotivasi siswa untuk meningkatkan hasil belajar. Dengan demikian, pembelajaran kooperatif melatih siswa untuk mempunyai kemampuan sosial, yaitu kemampuan saling bekerjasama dan bertanggungjawab untuk mencapai tujuan bersama (Rofiq, 2010:4).Model pembelajaran Teams Games Tournament memiliki banyak kesamaan dengan $S T A D$, bedanya hanya menambahkan dimensi kegembiraan yang diperoleh dari penggunaan permainan berupa turnamen. Sumarmi (2012:59) mengungkapkan bahwa anggota tiap kelompok akan saling membantu dalam mempersiapkan diri untuk turnamen dengan mempelajari lembar kegiatan secara bersama. Model pembelajaran ini juga menambah tanggungjawab individual siswa.Ketika pertandingan dimulai, perwakilan kelompok tidak boleh dibantu oleh pihak manapun dalam menjawab soal turnamen. Turnamen melatih siswa lebih giat belajar dengan meningkatkan rasa kompetisi siswa agar menang dalam turnamen. Langkah-langkah model pembelajaran Teams Games Tournament 
yang peneliti ambil yaitu: penyajian materi, pembentukan kelompok, game turnamen dan penghargaan kelompok.

Pembelajaran kooperatif tipe $T G T$ dapat berhasil dengan baik seperti yang pernah dilakukan oleh peneliti sebelumnya. Hasil penelitian Rikki (2012) menunjukkan adanya peningkatan hasil belajar dari $48,8 \%$ hingga $88,37 \%$. Model pembelajaran ini cocok dilaksanakan diberbagai jenjang pendidikan terutama SMP. Masa usia di SMP adalah usia yang masih sangat labil dimana siswa mempunyai rasa yang tinggi akan diperhatikan dan mempunyai jiwa kompetitif yang tinggi pula, oleh karena itu kita sebagai pendidik harus mengarahkan potensi tersebut sesuai porsinya. Situasi ini juga berlakubagi kelas VII-B di SMP PGRI 6 Malang yang terkenal ramai dan aktif dalam hal bercanda, tapi pasif dalam proses pembelajaran di kelas. Selain itu, kelas ini heterogen dalam latar belakang dan prestasi siswa,sehingga berdasarkan anjuran guru matematika SMP PGRI 6 Malang, kelas tersebut sangat cocok untuk dijadikan kelas penelitian dengan menggunakan penerapan pembelajaran kooperatif tipe $T G T$.

Berdasarkan hal tersebut, peneliti tertarik untuk melakukan penelitian terkait pembelajaran kooperatif tipe TGT.Hal ini dimaksudkan untuk mendorong guru dan siswa melaksanakan praktek pembelajaran secara aktif, sehingga diharapkan dapat tercapai peningkatan hasil belajar secara optimal.Adapun fokus penelitian ini adalah mendiskripsikan penerapan pembelajaran kooperatif tipe Teams Games Tournament yang dapat meningkatkan hasil belajar matematika siswa kelas VII-B SMP PGRI 6 Malang.

Kegunaan penelitian ini yaitu diharapkan siswa setelah mengikuti pembelajaran kooperatif tipe Teams Games Tournament dapat lebih giat belajar lagi, sehingga hasil belajar siswa akan meningkat mencapai KKM yang telah ditetapkan.Selain itu, kegunaan penelitian ini bagi guru adalah sebagai masukan dalam memperluas wawasan tentang berbagai model pembelajaran yang menyenangkan sepertipenerapan model pembelajaran Teams Games Tournament.

\section{Metode Penelitian}

Penelitian ini dilaksanakan di SMP PGRI 6 Malang. Menurut Musfiqon (2012:70) paradigma penelitian kualitatif adalah cara berpikir secara induktif. Definisi secara singkatnya adalah penelitian kualitatif merupakan penelitian yang jenis datanya bersifat deskriptif,baik berupa kalimat, pernyataan, dokumen, maupun data lain untuk dianalisis secara kualitatif. Pendekatan yang digunakan dalam penelitian ini merupakan prosedur penelitian yang menghasilkan data deskriptif berupa kata-kata tertulis atau lisan dari orang-orang dan perilaku yang diamati.Peneliti menjabarkan satiap proses dengan mendeskripsikan hal-hal yang diamati, sehingga dapat dikatakan bahwa pendekatan yang dilakukan dalam penelitian ini adalah pendekatan kualitatif.

Penelitian ini dimaksudkan untuk memperbaiki praktik pembelajaran didalam kelas agar memberikan hasil yang lebih baik. Adapun perbaikan praktik pembelajaran dilakukan pada saat melaksanakan model pembelajaran kooperatif tipe $T G T$. Proses dimulai dari tahapan perencanaan, tindakan, pengamatan dan refleksi. Berdasarkan penjabaran tersebut, maka penelitian ini berjenis PTK (Penelitian Tindakan Kelas). Kunandar (2010:5) menyebutkan bahwa PTK merupakan suatu kegiatan yang dilakukan oleh guru atau bersamasama dengan orang lain (kolaborasi) yang bertujuan untuk memperbaiki atau 
meningkatkan mutu proses pembelajaran di kelas.

Subyek penelitian ini adalah siswa kelas VII-B SMP PGRI 6 Malang yang berjumlah 24. Pemilihan sumber data dilakukan berdasarkan pertimbangan guru matematika. Pertimbangan yang diambil adalah siswa kelas tersebut mempunyai kemampuan yang heterogen.

Prosedur pengumpulan data yang digunakan meliputi:

1. Tes yang dilakukan di akhir siklus sebanyak dua kali berupa soal-soal yang berhubungan dengan materi aritmetika sosial. Tes bertujuan untuk mengetahui hasil belajar siswa setelah diberikan tindakan

2. Observasi yang dilakukan bertujuan untuk mengamati semua kegiatan di kelas selama proses belajar mengajar berlangsung. Kegiatan yang diamati meliputi aktivitas peneliti sebagai pengajar dan aktivitas siswa selama proses pembelajaran berlangsung ketika diskusi dan mengikuti turnamen. Observasi terhadap peneliti dilakukan oleh guru mata pelajaran matematika, sedangkan observasi terhadap kegiatan siswa dilakukan oleh teman sejawat.

3. Wawancara digunakan untuk mengetahui tanggapan siswa terhadap penerapan model $T G T$ di kelas. Wawancara merupakan instrumen penunjang bagi peneliti.Wawancara dimaksudkan untuk melengkapi dan menambah keakuratan data hasil observasi dan hasil tes.Wawancara dilakukan dengan mendalami secara langsung subjek penelitian.

Teknik analisis data yang digunakan meliputi:

1. Mereduksi data berarti merangkum, memilih hal-hal pokok, memfokuskan pada hal-hal yang penting, mencari tema dan pola, dan membuang yang tidak perlu. Pada tahap ini yang dilakukan adalah menyeleksi, memfokuskan, dan menyederhanakan semua data yang diperoleh. Dalam proses ini, data yang diperoleh dari tes akhir, catatan hasil observasi, dipilih dan diklasifikasikan untuk mendapatkan data yang dibutuhkan, sehingga menjadi sebuah informasi penting yang memungkinkan peneliti dapat menarik kesimpulan.

2. Penyajian data yang dapat dilakukan dalam bentuk uraian singkat, gambar dan bagan, Dalam penelitian ini, data yang paling sering digunakan adalah data berupa teks yang bersifat naratif. Data yang telah disajikan selanjutnya dibuat penafsiran dan evaluasi untuk perencanaan tindakan selanjutnya.

3. Menarik kesimpulan yaitu memberikan kesimpulan terhadap hasil penafsiran dan evaluasi yang mencakup pencarian makna data serta pemberian penjelasan. Selanjutnya dilakukan verifikasi, yaitu menguji kebenaran dan ketepatan makna yang diperoleh melalui pengecekan keabsahan data.

Menurut Moleong (2010:327) untuk menjamin keabsahan data, digunakan teknik kriteria derajat kepercayaan. Dalam penelitian ini derajat kepercayaan dilakukan dengan 3 cara, yakni: (1) Ketekunan pengamatan, (2) Triangulasi dan (3) Pemeriksaan teman sejawat. Tahap-tahap yang dilaksanakan dalam penelitian ini disesuaikan dengan model pembelajaran $T G T$ dan siklus penelitian tindakan.

Dalam penelitian ini minimal terdapat tiga tahap yaitu:

1. Tahap pra tindakan, Pada tahap ini kegiatan yang dilakukan peneliti antara lain:

a. Menentukan lokasi penelitian.

b. Menemui Kepala sekolah untuk izin penelitian. 
c. Melaksanakan observasi awal berupa pengamatan secara langsung proses pembelajaran di kelas dan wawancara dengan guru matematika untuk mengetahui secara konkrit kegiatan belajar mengajar dikelas.

d. Meminta nilai ulangan siswa kepada guru matematika untuk menentukan pembentukan kelompok.

e. Mendiskusikan rencana pelaksanaan pembelajaran dengan guru matematika. f. Menetapkan waktu penelitian berdasarkan pertimbangan guru matematika.

2. Tahap Pelaksanaan

Tahapan penelitian merupakan suatu rangkaian siklus yang berkelanjutan. Menurut Arikunto (2012:16) penelitian tindakan kelas sebagian besar lazim menggunakan 4 tahapan, yaitu: a) perencanaan, b) pelaksanaan, c) pengamatan, dan d) refleksi.

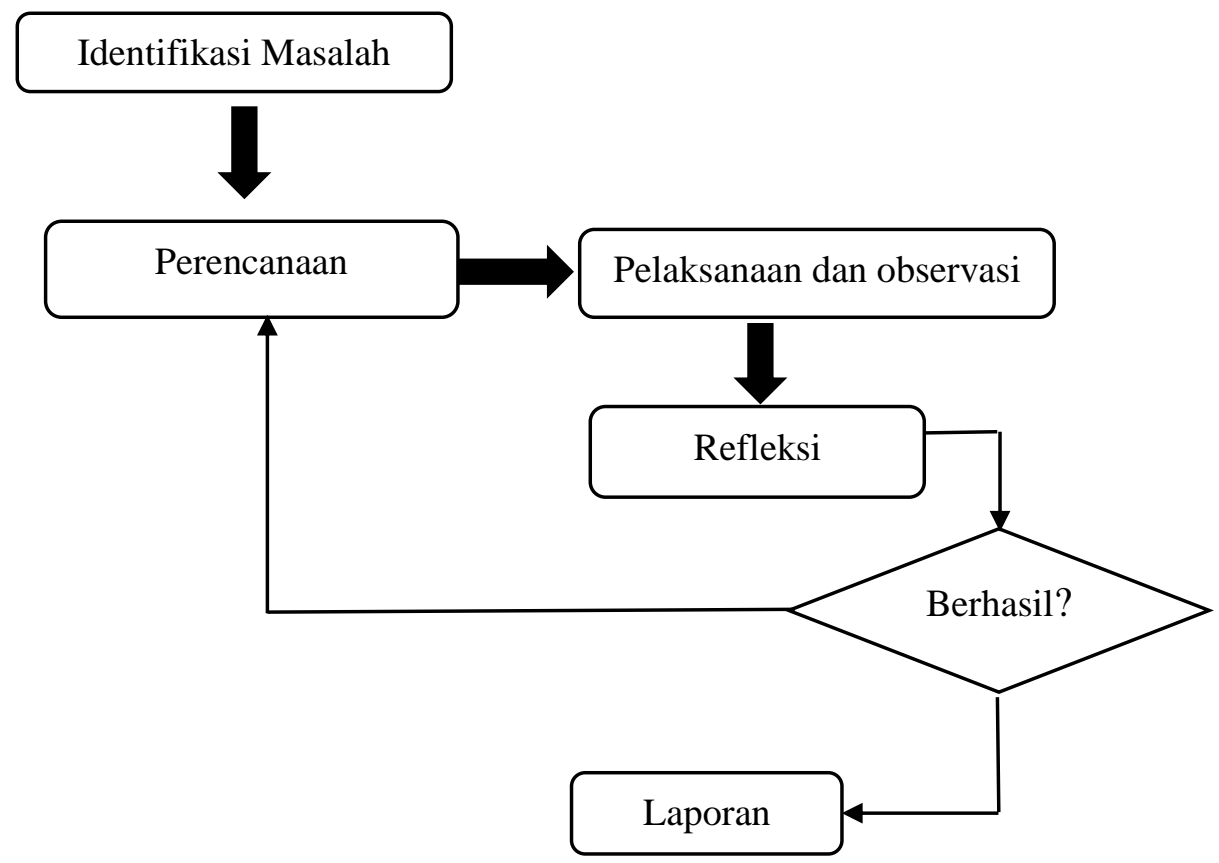

Gambar 2. Bagan Penelitian Tindakan Kelas (Classroom Action Research)

a. Perencanaan (planning)

Peneliti menentukan titik atau fokus peristiwa yang perlu mendapat perhatian khusus untuk diamati, kemudian membuat sebuah instrumen pengamatan untuk membantu peneliti merekam fakta yang terjadi selama tindakan berlangsung.

Beberapa hal yang disiapkan dalam perencanaan adalah sebagai berikut:
1) Menyusun rencana pelaksanaan pembelajaran (RPP) yang sesuai dengan langkah-langkah model pembelajaran $T G T$.

2) Menyiapkan kartu yang berisi soal turnamen dan bahan ajarmateri aritmetika sosial yang digunakan pada saat pembelajaran.

3) Menyiapkan lembar observasi kegiatan guru dan aktivitas siswa.

4) Menyiapkan soal tes akhir siklus 
b. Pelaksanaan/tindakan (acting)

Pelaksanaan tindakan yang dimaksud dalam penelitian ini adalah melaksanakan pembelajaran sesuai prosedur yang telah ditentukan, yaitu pembelajaran materi aritmetika sosial melalui model pembelajaran $T G T$ dengan tujuan untuk meningkatkan hasil belajar matematika siswa.

dilakukan:

$$
\text { Adapun kegiatan yang }
$$

1) Guru membagi siswa ke dalam 6 kelompok (tim) yang beranggotakan 4-5 siswa. Pembagian siswa ini berdasarkan perolehan nilai ulangan siswa dan diskusi dengan guru matematika.

2) Guru membagikan modul materi pokok aritmetika sosial, memberikan tugas kepada masing-masing kelompok untuk mengerjakan LKS dan melaksanakan game tournament.

3) Pada akhir pembelajaran guru memberikan tes akhir siklus yang bertujuan untuk mengetahui ada tidaknya peningkatan hasil belajar siswa. Setelah kegiatan belajar selesai, subjek penelitian akan diwawancarai untuk mengetahui kondisi yang lebih real dari penelitian.

c. Observasi (observating)

Observasi dilakukan untuk merekam proses yang terjadi selama pembelajaran berlangsung. Kegiatan observasi menyatu dalam pelaksanaan tindakan maka perlu dikembangkan sistem dan prosedur observasi yang mudah dan cepat dilakukan. Kegiatan yang dilakukan pada tahap ini adalah mengamati dan mengisi lembar pengelolaan pembelajaran guru.

d. Refleksi (reflecting)

Tahap refleksi ini dilakukan untuk melihat proses pelaksanaan tindakan secara keseluruhan.
Refleksi dalam penelitian ini adalah kegiatan menganalisis data-data yang diperoleh dari hasil observasi. Hasil observasi tersebut digunakan sebagai dasar untuk menentukan keberhasilan tindakan sesuai dengan kriteria yang sudah ditentukan.

Peneliti bersama pengamat mengevaluasi hasil pelaksanaan tindakan sebagai bahan pertimbangan apakah siklus pertama telah mencapai kriteria keberhasilan atau belum, jika pada langkah ini ditemukan masalah dan hasil tes siklus belum mencapai Kriteria Ketuntasan Minimal (KKM) yang ditetapkan maka peneliti mengulangi siklus penelitian dengan merevisi perencanaan pada siklus berikutnya sampai mendapatkan hasil yang maksimal.

3. Tahap Pelaporan

Tahap pelaporan adalah tahap terakhir setelah penelitian dikatakan berhasil. Pada tahap ini, peneliti melaporkan seluruh hasil penelitian yang telah dilakukan dilapangan. Laporan yang dibuat dalam bentuk laporan tertulis.

Keberhasilan tindakan meliputi dua komponen yaitu kriteria keberhasilan hasil belajar, dan kriteria keberhasilanproses. Kriteria keberhasilan hasil belajar dilihat dari tes evaluasi siklus. Siswa dikatakan tuntas dalam pembelajaran matematika, jika memperoleh nilai Kriteria Ketuntasan Minimal (KKM) yang ditentukan sekolah yaitu sebesar 71 dengan banyaknya minimal $70 \%$ siswa tuntas belajar. Kriteria keberhasilan proses ditentukan dengan menganalisis hasil observasi.

\section{Hasil dan Pembahasan}

Hasil analisis pada nilai ulangan semester 1 menunjukkan bahwa rata-rata nilai siswa adalah $63,6 \%$. Dengan kriteria ketuntasan minimal 71 , hanya $32,1 \%$ 
siswa yang tuntas belajar, sedangkan $67,9 \%$ siswa tidak tuntas belajar.
Analisis data hasil tes siklus I dan siklus II siswa dapat dilihat pada tabel berikut:

Tabel 1. Analisis Hasil Tes Siklus I dan Siklus II

\begin{tabular}{lcc}
\hline \multicolumn{1}{c}{ Keterangan } & Hasil tes siklus I & Hasil tes Siklus II \\
Nilai rata-rata & 77,45 & 80 \\
Presentase ketuntasan & $63,6 \%$ & $83,3 \%$ \\
\hline
\end{tabular}

Terlihat pada Tabel 1. bahwa ketuntasan hasil belajar siswa pada siklus I belum memenuhi kriteria hasil belajar sehingga siklus I belum bisa dikatakan berhasil dan melanjutkan tindakan pada siklus II. Pada siklus II presentase ketuntasan belajar siswa sudah mencapai lebih dari $70 \%$, yaitu $83,3 \%$ sehingga siklus sudah berhasil dan tindakan bisa dihentikan. Kriteria keberhasilan tindakan dapat dilihat pada tabel berikut:

Tabel 2. Analisis Lembar Observasi Aktivitas Guru dan Siswa Siklus I dan Siklus II Tes Siklus I (pertemuan) Tes Siklus II (pertemuan)

Keterangan

Aktivitas Peneliti (Guru)

Aktivitas Siswa
I

$94,64 \%$

$\mathbf{8 5 , 7 1 \%}$
II

$96,43 \%$

$\mathbf{8 9}, 78 \%$
I

$96,1 \%$

91,1\%
II

$96,43 \%$

$\mathbf{9 2 , 8 \%}$
Observasi awal yang dilakukan peneliti menunjukkan bahwa siswa terlihat pasif di kelas, hanya mencatat tulisan di papan tulis, mendengarkan guru tanpa adanya timbal balik, dan selanjutnya mengerjakan tugas dari guru. Guru juga sering meninggalkan siswa saat pembelajaran sehingga siswa merasa kurang diperhatikan oleh gurunya. Selain itu, pembelajaran yang digunakan kurang bervariasi menyebabkan siswa bosan dalam proses belajar, sehingga berdampak pada hasil belajar yang diperoleh siswa. Nilai siswa berada dibawah nilai KKM yang ditetapkan.

Pemilihan model pembelajaran dapat menjadi alternatif terbaik dalam meningkatkan minat siswa terhadap matematika, karena ada variasi pembelajaran dalam kelas yang menjadikan siswa aktif sehingga dapat meningkatkan hasil belajar siswa.
Penggunaan variasi dalam pembelajaran dapat mengatasi kejenuhan dan kebosanan siswa terhadap pembelajaran yang monoton, sehingga siswa mendapatkan pembelajaran lebih bermakna dan optimal (Rusman, 2012:85).

$$
\text { Model pembelajaran yang }
$$
menyenangkan dan mengurangi kebosanan siswa sehingga dapat meningkatkan hasil belajar siswa dalam penelitian ini yaitu model pembelajaran Teams Games Tournament. Model pembelajaran ini cocok digunakan untuk siswa yang mempunyai jiwa kompetitif tinggi. Pendidik harus mengarahkan potensi itu dalam kompetisi yang sehat seperti turnamen pada model $T G T$ ini. Persaingan yang sehat baik secara kelompok ataupun individu memungkinkan siswa berusaha dengan sungguh-sungguh untuk memperoleh 
hasil yang terbaik, sehingga berpengaruh terhadap keberhasilan proses pembelajaran siswa (Sanjaya, 2011:31).

1. Tahap Tindakan Siklus I

Peneliti mengawali tindakan siklus I dengan mengucapkan salam, mengabsen siswa dan menanyakan kabar supaya siswa merasa lebih santai. Kemudian, peneliti menyampaikan tujuan pembelajaran dan model pembelajaran yang akan digunakan. Supaya membangkitkan motivasi belajar matematika, siswa perlu tahu bahwa pelajaran tersebut sangat dibutuhkan dan bermanfaat dalam kehidupan sehari-hari (Dimyati dan Mudjiono, 2013:42).

Peneliti menjelaskan materi mengenai harga pembelian, harga penjualan, untung dan rugi kepada siswa. Peneliti mengawali dengan sebuah pertanyaan yang dapat menarik perhatian siswa. Selain menumbuhkan perhatian siswa, tanya jawab dapat mengembangkan kemampuan siswa dengan pengetahuan dan pengalaman yang dimilikinya (Roestiyah, 2012:130).

Selanjutnya peneliti melakukan pembentukan kelompok sesuai dengan persiapan pada tahap pratindakan. Pembentukan kelompok ditentukan oleh peneliti terdiri dari 4-5 siswa dengan kemampuan dan latarbelakang yang berbeda (heterogen). Hal ini dimaksudkan agar setiap anggota kelompok dapat saling bekerjasama dan saling membantu untuk memahami materi pelajaran sehingga diharapkan setiap anggota dapat memberikan konstribusi terhadap kelompoknya (Suparmi, 2012:6).

Setelah siswa berkumpul dengan kelompoknya, peneliti membagikan LKS kepada setiap kelompok. Peneliti meminta siswa mengerjakan LKS agar lebih memahami materi. Peneliti menginformasikan bahwa setelah diskusi, kegiatan berikutnya adalah presentasi hasil kerja kelompok dilanjutkan dengan turnamen. Dengan demikian, diharapkan siswa benar-benar menguasai materi untuk memudahkan menjawab soal turnamen. Melalui belajar kelompok, setiap anggota kelompok dipastikan memahami materi yang sedang dipelajari dan mempersiapkan anggotanya untuk menghadapi turnamen (Sumarmi, 2012:62).

Setelah diskusi kelompok, peneliti meminta perwakilan salah satu kelompok untuk mempresentasikan hasil diskusi dan kerja kelompoknya. Beberapa siswa masih kurang percaya diri dalam mempresentasikan hasil diskusi kelompoknya di depan kelas. Oleh karena itu, peneliti harus memberikan penekanan kepada siswa bahwa ia dapat mengatasi segala hambatan dan pasti berhasil danrasa percaya diri siswa menjadi meningkat (Aristiani, 2016:7).

Kegiatan selanjutnya adalah turnamen. Siswa sangat antusias dan merasa tertantang serta senang saat mengikuti turnamen, sehingga kegiatan ini menumbuhkan motivasi siswa untuk lebih aktif dalam kegiatan pembelajaran. Permainan dalam turnamen merupakan salah satu aktivitas yang dapat menarik minat siswa dalam belajar.Permainan dapat menimbulkan rasa kewaspadaan danpeningkatan konsentrasi.

Pada akhir turnamen, peneliti memberikan penghargaan bagi 3 kelompok terbaik. Penentuan kelompok terbaik berdasarkan nilai rata-rata kelompok. Penghargaan yang diberikan peneliti berupa hadiah sereal yang dibagikan kepada masing-masing anggota kelompok terbaik. Pemberian hadiah diharapkan dapat meningkatkan rasa senang dan bangga pada hasil kelompok dan memotivasi siswa untuk lebih giat lagi dalam belajar. Hadiah adalah alat untuk siswa supaya dapat merasa senang karena hasil kerjanya mendapat penghargaan (Purwanto, 2007:182). 
Agar siswa tetap belajar sekalipun di rumah, peneliti memberikan tugas rumah yang harus dikerjakan siswa dan akan dibahas pada pertemuan berikutnya. Tugas rumah diberikan sebagai bekal tambahan pengalaman dan pengetahuan kepada siswa yaitu siswa mengerjakan soal latihan yang diberikan guru (Suprihatiningrum, 2013:292). Peneliti menginformasikan bahwa pada pertemuan berikutnya akan diadakan tes akhir siklus I dengan materi harga jual, harga beli, untung dan rugi yang telah dipelajari.

Pertemuan berikutnya diawali dengan membahas 2 soal yang merupakan tugas rumah. Selanjutnya dilakukan tes berbentuk uraian. Tes dilakukan agar peneliti mengetahui sejauh mana siswa memahami materi yangtelah dipelajari. Tes uraian menuntut siswa untuk dapat menjawab soal dengan mengingat-ingat rumus yang telah dipelajari (Arikunto, 2012:177).

2. Tahap Tindakan Siklus II

Pada tindakan siklus II, peneliti memperbaiki kekurangan-kekurangan yang terjadi pada siklus I. Beberapa fakta yang mempengaruhi ketidakberhasilan tindakan pada siklus I adalah tidak semua siswa aktif dalam pembelajaran dan diskusi kelompok. Ketika turnamen, ada siswa yang ramai sendiri hingga mengganggu aktivitas temannya.

Upaya peneliti untuk mengatasi hal tersebut salah satunya adalah memilih ketua kelompok. Untuk masing-masing kelompok, dipilih ketua kelompok dengan ketentuan yang telah ditetapkan oleh peneliti. Ketua kelompok bertugas memberikan pengarahan kepada anggotanya tentang masalah yang akan didiskusikan dan membuka kesempatan kepada semua anggota untuk mengungkapkan pendapatnya, sehingga semua aktif berdiskusi (Anam, 2015:147).
Pada siklus II, siswa lebih aktif dalam kegiatan diskusi. Masing-masing kelompok kompak saling bekerja sama dalam mengerjakan dan mencari jawaban dari soal-soal pada LKS. Siswa terlihat saling memotivasi, saling mengingatkan, bahkan saling beradu argumen dan pendapat. Mereka belajar untuk memahami materi supaya dapat menyelesaikan soal pada turnamen dan tes.

Ketika tes akhir siklus, tampak siswa serius dalam mengerjakan soal tes. Namun, masih ada siswa yang kurang percaya diri sehingga mau mencontek hasil pekerjaan siswa lain. Peneliti langsung memberikan peringatan dan suasana kelas menjadi aman terkendali.Semua siswa harus dibiasakan mandiri dalam mengerjakan soal tes. Rasa percaya diri yang tinggi ditunjukkan dengan tidak mencontoh pekerjaan siswa lain, ini menunjukkan bahwa siswa yakin dengan kemampuannya dan mampu menguasai materi yang telah dipelajari (Kushartanti, 2009:6).

Persentase ketuntasan hasil belajar siswa dari siklus I meningkat dari 63,6 menjadi $83,3 \%$ pada siklus II. Hal ini berarti siklus II sudah memenuhi kriteria keberhasilan yaitu dengan presentase ketuntasan minimal $70 \%$. Sedangkan analisis presentase nilai yang diperoleh guru (peneliti) dan siswa juga sudah mecapai lebih dari 70\%.Halini menunjukkan bahwa kriteria pelaksanaan tindakan dapat dikatakan berhasil. Dengan demikian model pembelajaran kooperatif tipe $T G T$ dapat meningkatkan hasil belajar siswa.

\section{Kesimpulan}

Model pembelajaran TGT (Teams

Games Tournament) membuat siswa ingin bersaing secara sportif sehingga siswa semakin semangat belajar.Model pembelajaran ini membuat siswa yang berkemampuan tinggi tidak mendominasi 


\section{Pi:Mathematics

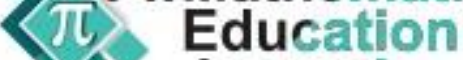 \\ Journal}

pembelajaran dan memberikan kesempatan belajar bagi siswa yang berkemampuan sedang atau rendah, sehingga siswa juga berlatih bersosialisasi dan bekerjasama dalam kelompok. Aktivitas peneliti pada lembar observasi meningkat dari94,64\% pada siklus I menjadi $96,1 \%$ pada siklus II. Aktivitas siswa meningkat dari $85,71 \%$ pada siklus I menjadi $91,1 \%$ pada siklus II. Pada tes akhir siklus I, banyaknya siswa yang mencapai KKM sebanyak 14 siswa dari 22 siswa,dengan kata lain sebanyak 63,6\% siswa mencapai ketuntasan. Pada tes akhir siklus II, banyaknya siswa yang mencapai KKM sebanyak 20 siswa dari 24 siswa atau sebanyak 83,3\% siswa mencapai ketuntasan. Dengan demikian, hasil belajar siswa pada siklus II mengalami peningkatan sebesar 19,7\%.Dapat disimpulkan bahwa model pembelajaran kooperatif tipe $T G T$ dapat meningkatkan hasil belajar siswa.

\section{Daftar Rujukan}

Anam, K. (2015). Pembelajaran Berbasisi Inkuiri: Metode dan Aplikasi. Yogyakarta: Pustaka Pelajar.

Arikunto, S. (2012). Dasar-Dasar Evaluasi Pendidikan. Jakarta: Bumi Aksara.

Aristiani, R. (2016). Meningkatkan Percaya Diri Siswa Melalui Layanan Informasi Berbantuan Audiovisual. Jurnal Konseling Gusjigang, (online), 2 (2): 7, (http://media.neliti.com), diakses tanggal 5 juni 2018

Dimyati dan Mudjiono. (2013). Belajar \& Pembelajaran. Jakarta: Rineka Cipta.

Hariyani, Sri. (2018). Berpikir Outside The Box Mahasiswa dalam Menyelesaikan Masalah Barisan Bilangan. UNION: Jurnal Pendidikan Matematika, 6 (1) : 61 $-70$.
Kunandar. (2010). Langkah Mudah Penelitian Tindakan Kelas sebagai Pengembangan Profesi Guru. Jakarta: Rajawali Pers.

Kushartanti, A. (2009). Perilaku Menyontek Ditinjau dari Kepercayaan Diri, Jurnal Ilmiah Berkala Psikologi,(online), 11 (2):6,(http://publikasiilmiah.ums.ac. id) diakses tanggal 5 juni 2018

Moleong, L.J. (2013). Metodologi Penelitian Kualitatif Edisi Revisi. Bandung: PT. Remaja Rosdakarya.

Musfiqon. (2012). Metodologi Penelitian Pendidikan. Jakarta: PT Prestasi Pustakarya.

Purwanto, N.M. (2007). Psikologi Pendidikan. Bandung : Remaja RosdakaryaRofiq, M.N.2010. Pembelajaran Kooperatif (Cooperatif Learning) dalam Pengajaran Pendidikan Agama Islam. Jurnal Falasifa, (online) 1 (1):4,

(http://jurnalfalasifa.files.wordpress .com), diakses tanggal 7 juni 2018

Rikki, P. (2012). Penerapan Model Pembelajaran Kooperatif Tipe Teams Games Tournament (TGT) untuk Meningkatkan Hasil Belajar Matematika Siswa Kelas VIII A SMPN 17 MALANG. Skripsi tidak diterbitkan. Malang: Universitas Kanjuruhan Malang

Roestiyah.(2008). Strategi Belajar Mengajar dalam CBSA. Jakarta: Rineka Cipta

Rusman. (2013). Model-Model Pembelajaran Mengembangkan Profesionalisme Guru. Jakarta: Rajawali Pers.

Sanjaya, W. (2011). Strategi Pembelajaran Berorientasi Standar Proses Pendidikan. Jakarta: Kencana Prenada Media.

Sumarmi. (2012). Model-Model Pembelajaran Geografi.Malang: Aditya Media Publishing. 
Suparmi. (2012). Pembelajaran Kooperatif dalam Pendidikan Multikultural. Jurnal Pembangunan Pendidikan, (online) 11 (1):6, (http://portalgaruda.org), diakses tanggal 5 juni 2018

Suprihatiningrum, J. (2013). Strategi Pembelajaran: Teori \& Aplikasi. Jogjakarta: Ar-Ruzz Media. 